\title{
Demonstrative of Ciacia Language
}

\author{
La Yani Konisi \\ \{layani@uho.ac.id\} \\ Halu Oleo University Kendari, Indonesia
}

\begin{abstract}
The category of demonstrative in several languages is very limited. In Ciacia language (CL), the classification of CL is not only based on the distance of speaker but also the direction factor. This paper investigated the category of demonstrative in CL. It includes the classification of $\mathrm{CL}$ demonstrative based on distance and direction. The data were collected through interview method with recordingand noting techniques. The data was analyzed through apportioned and changing methods. Based on the result of data analysis, demonstrative of CL language is classified based on the forms, they are (a) single form, (b) integral form, (c) compound form. Based on distance and direction, it can be classifiedas follow (1) rather closed with all directions, (2) closed with all directions, (3)rather far: (a) upward, (b) sideways, (c) downward; and far position: (a) forward, (b) upward/high, and (c) backward/far. CL has base form demonstrative such as nai/nakee 'this', naiamo, naianomo, nakeenomo 'this', Ncuia/cukee 'that', ncuiamo, ncuinomo, cukeenomo 'that', tamaia, tamangkee (-mo/-nomo) 'that, there', tangeia, tangia (-mo/-nomo) 'that, there', lumaia/lumangkee, lumaia/lumai/lumangkee (-no/-nomo), 'that, there'; and compound form such as kaina/kanakee, kainamo/kanakenomo 'here' and kaincu/kacukee, kacukeenomo 'there'..
\end{abstract}

Keywords - Demonstrative, direction, distance, Ciacia language

\section{Introduction}

Demonstrative in every language has different form and classification although all language have form and category of demonstrative. One language has demonstrative which is classified based on distance only like Indonesian language. Other languages have varied forms such as Ciacia language. Ciacia language has demonstrative which is classified basedn distance and direction, and in base and integral forms. Ciacia language is often called as Cia language (abbreviated by CL) spoken in Buton island, Southeast Sulawesi. It spreads to Buton Regency, Baubau town, Wakatobi Regency, and South Buton Regency. Now, CL also sopken and build one community in several regencies of Southeast Sulawesi such as North Buton Regency and even in Samarinda[1][2][3]. Discussion of demonstrative in this study used theories of Quirk and Greenbaum [4][5][6] [7] [8] [9][10]. [8] Demonstrative is a word that refers to something in terms of distance from speaker. Demonstrative as any item that function as pointer/demonstrative or reference (deictic) [7]. [9]Demonstrative in four categories, namely determiner demonstrative, pronoun demonstrative, adverbial demonstrative, and identifer 
demonstrative. Generally, there are four kinds pronoun demonstrative in English, namely this, that, these, and those [10]. Category of pronoun demonstrative is based on number (singular and plural) and distance (closed and far). This and these used to refers something which is closed in place, time, and psychology, while that and those to refers something which is far [10]. [4] There are other words used as reference, namely here/there and now/then. Here/there used to refers place, while now/then used to refers time.

Basically, there are several previous studies which are relevant to this study. Konisi [1] studied construction of active-passive verb in Ciacia language. [11] Investigated morphology structure of Ciacia language. Besides, [11] also studied phrase structure of Ciacia language. In 2007, [2] discussed sentence structure of Ciacia language. Last, Konisi (2019) studied in his dissertation about verbal clause construction of Ciacia language. Those previous studies did not discuss demonstrative in Ciacia language.

Based on the explanation and previous studies above, it has not been found particularly study of demonstrative categories in Ciacia language. This study thus investigated the category of demonstrative in CL. It includes the classification of CL demonstrative based on distance and direction. Classification of based on the distance can be divided further in rather close, close, far, rather far, and very far. Likewise, classification of based on the direction can divided in forward, sideways, downward, and towards the back (passed).

\section{Methods}

This study used qualitative descriptive method. The sources of data are from informants as native speakers of CL. It was collected through interview with recording technique. It was then transcibed and analyzed by apportioned and changing techniques [12]. The data which have been transcribed are gropued based on the meaning and function. It was then described and analyzed based the catagory of demonstrative. The presentation of data was done inductively from data, analysis, discussion, and taking conclusion [13].

\section{Result and Discussion}

The category or form of demonstrative in CL can be explained in the description below.

\subsection{Base Form Demonstrative}

Nai/nakee 'this'

Nai and nakee used to refers something (things, person, and place) which is closed from speaker. Referred something is on various directions (front, sides, under, and above of speaker), can be touched with hand or finger. The form can be look at in the examples below.

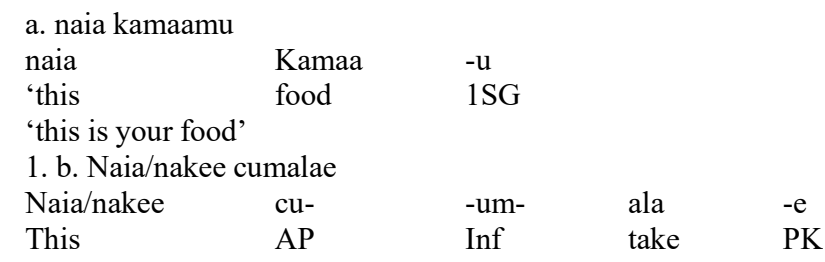


Data (1a) is base demonstrative of naia/nakee that refers to something closed from speaker. Naia/nakee is also used to choose closed things from speaker such as in data (1b)

Naiamo, naianomo, nakeenomo 'this'

Naiano/nainomo/nakeenomo/nakeenomo 'this' is categorized as integral form demonstrative, closed, and used to choose or refers to among other goods (after looking at).

\begin{tabular}{llllll}
\multicolumn{2}{l}{ 2. a. Naiamo/naianomo/nakeenomo nipiitau } & & & \\
Naia/nakee & $-\mathrm{mo} /$ nomo & ni- & pi- & ita & $-u$ \\
This & has/have & which & Pref & see & ISG
\end{tabular}

Forms of naiano/naianomo/nakeenomo also used to refers closed distance from speaker, and even can be touched by speaker.

Ncuia/cukee 'that'

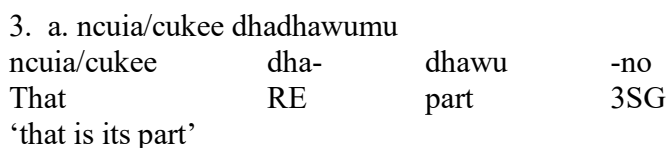

Ncuia/cukee is used to refer something closed from speaker, but it can not be touched. Its position are both in the front and sides of speaker.

Ncuiamo, ncuinomo, cukeenomo 'that'

$\begin{array}{llll}\text { 4. a. ncuiamo/ncuianomo/cukeenomo kadhongkomiu } & \\ \text { Ncuia/cukee } & -\mathrm{mo} / \text {-nomo } & \text { kadhongko } & \text {-miu } \\ \text { That } & \text { has/have } & \text { sarong } & \text { 2PL }\end{array}$

'that (they) are your sarongs'

Ncuiamo/ncuianomo/cukeenomo is used not only to refer something closed from speaker, but also to refer something in the front. However, demonstative of ncuiamo/ncuinomo is also used to refers something that come from in the front, while cukeenomo can not but only refers something in the front and has certainty meaning.

Tamaia, tamangkee (-mo/-nomo) 'that, there'

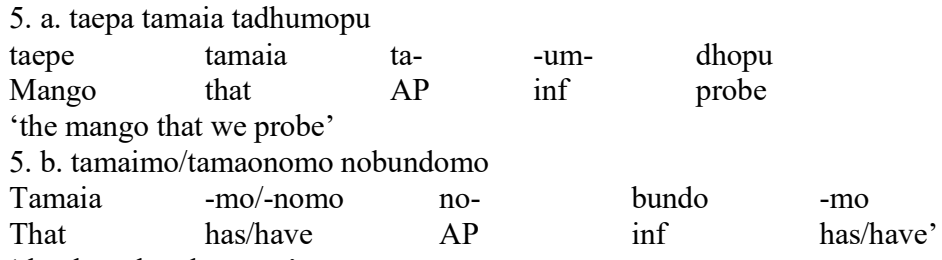

Data (5a) and (5b) used demonstrative of tamaia, tamaiamo/tamainomo. Although they are used to refers something which are far or high position and above position, and also used to refers something among others (certainty reference). Tangeia, tangia (-mo/-nomo) 'that, there'

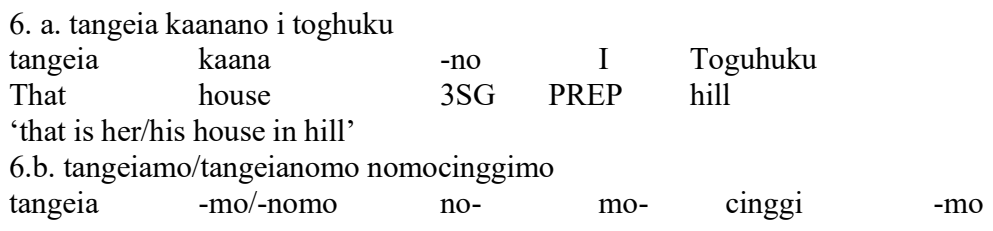


That has/have AP PREF high has/have

Tangeia (6a) is used to appoint something that is located upward or in high position, and seeing of speaker look at above. While, tangeiamo/tangeianomo (6b) is used not only to appoint upward but also give certainty position.

Lumaia/lumangkee, lumaia/lumai/lumangkee (-no/-nomo), 'that, there'

\begin{tabular}{|c|c|c|c|c|c|}
\hline lumaia & kacumpo & - miu & Ama & & \\
\hline That & iron & $2 \mathrm{PL}$ & father & & \\
\hline $\begin{array}{l}\text { 'that is } \\
\text { 7. b. lu }\end{array}$ & $\begin{array}{l}\text { iron' } \\
\text { ımai/ luman }\end{array}$ & o/-nor & & & \\
\hline Lumaia & -mo/-nom & no- & ci- & ita & -mo \\
\hline That & Has/have & $\mathrm{AP}$ & PREF & see & Has/have \\
\hline
\end{tabular}

lumaia (7a) is used to appoint something that is rather far and in the sideways of speaker, while lumaiamo/lumainomo (7b) used to appoint something among others to ascertain its position and also can be used to appoint something that come from sideways

$\mathrm{CL}$ also has demonstrative form dhawaia/dhawangkee which is used to appoint something that is rather far and downward of speaker; and longeia/longkee 'that' used to appoint something that is rather far and in the backward of speaker.

\subsection{Compound Form Demonstrative}

Compound form demonstrative is combination demonstrative of base form and other forms to show the position/location.

kaina/kanakee, kainamo/kanakenomo 'here'

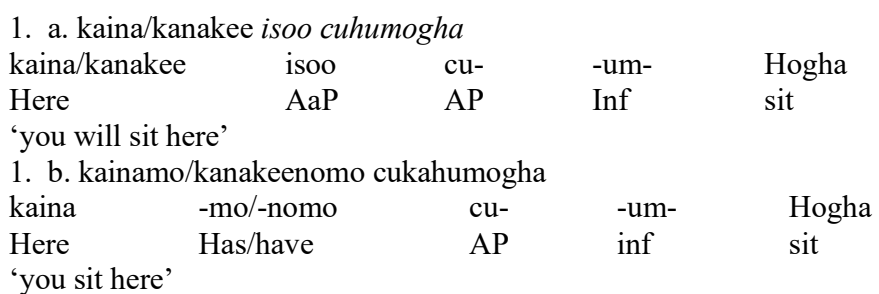

Kanakee is builded from morphemes $k a$ as location demonstrative and single morpheme nakee and morphemes -mo/-nomo. Kaina/kanakee (1a) used to appoint place that is closed from speaker, and it can be touched, while kainamo/kanakeenomo is also used (1b) to appoint place that is closed from speaker, and it emphasizes on the place (give certainty).

Kaincu/kacukee, kacukeenomo 'there'

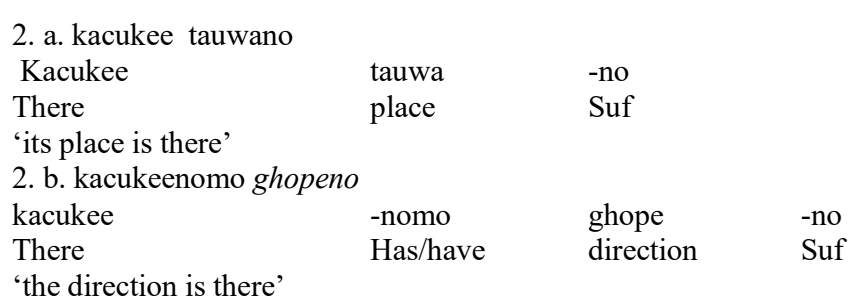


Data (2a) and (2b) used to appoint place which are further from speaker. Besides, data (2b) used to acertain the place.

Katamaia/katamangkee,katamai/katamangkee (-mo/-nomo), 'there'

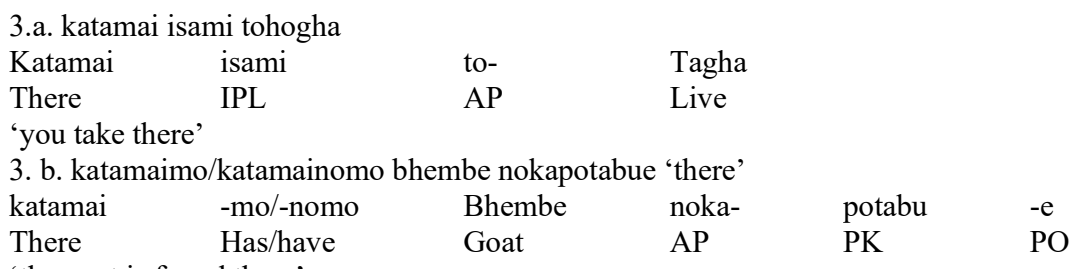

Data (3a) and (3b) used to appoint place which are further from speaker and its position is front-upward.

CL also has other compound form demonstratives. They are kadhawai/kadhawangkee (-no/nomo), 'there' used to appoint place which are further from speaker and its position is frontdownward; katamai, katamaimo/katamainomo, katamangkee, kayamangkeenomo 'there' used to appoint something in the front and upward; and kaitange(-no/-nomo) 'there' used to appoint something forward and upward; and kailonge/kailongkee (-no/-nomo) 'there' which is used to appoint place which are further from speaker and its position is backward.

\section{Conclusion}

The discussion in this paper gives more descriptions of demonstrative in Ciacia language. Demonstrative of CL language is classified based on the forms, they are (a) single form, (b) integral form, (c) compound form. Based on distance and direction, it can be classified as follow (1) rather closed with all directions, (2) closed with all directions, (3) rather far: (a) upward, (b) sideways, (c) downward; and far position: (a) forward, (b) upward/high, and (c) backward/far.

\section{References}

[1] K. La Yani, “Konstruksi Verba Aktif Bahasa Ciacia,” Padjadjaran University, Bandung, 1999.

[2] K. La Yani and A. Hidayat, "Struktur Kalimat Bahasa Ciacia," Universitas Halu Oleo, Kendari, 2007.

[3] K. La Yani and A. Hidayat, "Konstruksi Klausa Verbal Bahasa Ciacia," Udayana University, Bali, 2019.

[4] Q. R and G. S, A university grammar of English. Essex: Longman Group Limited, 1985.

[5] A. Hasan and E. Al, Bahasa Baku Bahasa Indonesia. Jakarta: Pustaka, 2010.

[6] K. Harimurti, Kelas Kata dalam Bahasa Indonesia. Jakarta: Gramedia, 2003.

[7] R. M. D. W., "Demonstratives: a cross-linguistic typology," Studies in Language, vol. 27, no. 1, pp. 61-122, 2003.

[8] R. J. C. and S. R, Dictionary of language teaching and applied linguistics, 4th ed. Harlow, UK: Pearson Educational Limited, 2010.

[9] D. H, Demonstratives: form, function and grammaticalization. Amsterdam: John Benjamins Publishing Company, 1999.

[10] A. F and J. Aarts, English Syntactic Structures. Oxford: Pergamon Press, 1982.

[11] K. La Yani and H. Ahid, "Struktur Frasa Bahasa Ciacia," Universitas Halu Oleo, Kendari, 2003. 
[12] A. L. Hakim, Sudarmiatin, and Sutrisno, "The Effect of Work Stress on Turnover Intention with Work Satisfaction and Commitment as Intervening Variable (Study at PT Infomedia Solusi Humanika in Malang)," European Journal of Business and Management, vol. 10, no. 12, pp. 8594, 2018.

[13] F. N. Anggita, "A Sociolinguistic Analysis of Taboo Words in Bad Teacher Movie," Quill Bahasa dan Sastra Inggris, vol. IV, no. 1, pp. 1-18, 2017. 